\title{
CONTENT OF THE SELECTED MACRO-ELEMENTS IN POTATO TUBERS (SOLANUM TUBEROSUM L.) TREATED WITH BIOSTIMULATORS
}

\author{
GugAŁA, M. ${ }^{1}$ - MYSTKOWSKA, I. ${ }^{2 *}$ - RoGÓŻ-MATYSZCZAK, A. ${ }^{3}$-ZARZECKA, K. ${ }^{1}$ - SIKORSKA, A. ${ }^{4}$ \\ ${ }^{I}$ Department of Agrotechnology, Siedlce University of Natural Sciences and Humanities, Prusa \\ 14, 08-110 Siedlce, Poland \\ (e-mail: gugala@uph.edu.pl,kzarzecka@uph.edu.pl) \\ ${ }^{2}$ Department of Agriculture, Pope John Paul II State School of Higher Education in Biala \\ Podlaska, Sidorska 95/97, 21-500 Biała Podlaska, Poland \\ ${ }^{3}$ Laboratory of Environmental Analyzes EKO-AGRO-TECH, Pope John Paul II State School of \\ Higher Education in Biala Podlaska, Sidorska 95/97, 21-500 Biała Podlaska, Poland \\ ${ }^{4}$ Department of Agriculture, The State Higher School of Vocational Education in Ciechanów, \\ 06-400 Ciechanów, Poland \\ (e-mail: aniasikorska6@wp.pl) \\ *Corresponding author \\ e-mail: imystkowska@op.pl
}

(Received 23 ${ }^{\text {rd }}$ Apr 2019; accepted 11 $1^{\text {th }}$ Jul 2019)

\begin{abstract}
The objective of research was to assess the selected mineral components (phosphorus, calcium and magnesium) in the tubers of edible potato. Field research was carried out in the years 2015-2017 with an application of biostimulators in individual farms in the town of Międzyrzec Podlaski (51 $59^{\prime} \mathrm{N}$ and $22^{\circ} 47^{\prime}$ E), Poland. The experiment was led by means of a split-plot method. The impact of two factors was tested. The first order factor were the three varieties of edible potato: Honorata, Jelly, Tajfun, while of the second order - four variants of applying biostimulators: Kelpak SL, Titanit, GreenOk, BrunatneBio Złoto and a control variant (potato plants sprayed with distilled water). Potato plants were treated with biostimulators three times (beginning of flowering, full flowering and after plant flowering). Within the presented research the applied biostimulators increased the content of selected mineral components in the tubers of tested varieties. Tubers of plants treated with BrunatneBio Złoto preparation were characterized by the largest content of phosphorus, calcium and magnesium in comparison to the plants from control object. The content of microelements in the tubers varied significantly depending on the genotype of the variety. The greatest concentration of phosphorus was noted in the tubers of Tajfun variety, while in case of magnesium - Honorata variety. Large amount of rainfall in 2017 contributed to the occurrence of an increase of the content of phosphorus, calcium and magnesium in potato tubers. Average content of phosphorus amount to, on average: $3.4 \mathrm{~g} \cdot \mathrm{kg}^{-1}$, calcium $0.73 \mathrm{~g} \cdot \mathrm{kg}^{-1}$, and magnesium $1.36 \mathrm{~g} \cdot \mathrm{kg}^{-1}$.
\end{abstract}

Keywords: variant, variety, phosphorus, calcium, magnesium

\section{Introduction}

The nutritional value of potatoes (Solanum tuberosum L.), apart from carbohydrates, protein and vitamins, is determined by the content of mineral components (Leszczyński, 2012; Wójcik -Stopczyńska et al., 2012). The following are of particular importance: phosphorus, calcium, magnesium - having alkali-forming actions, their presence in food neutralizes the acidifying meat, fish and cereal product properties (Tajner-Czopek, 2006). These elements perform mainly the building and physiological functions in a plant, further to deciding about its dietetic values (Leszczyński, 2012; Wierzbicka, 
2012). Phosphorus is the key component of compounds which are decisive for the energetic processes. It forms part of specific proteins and participates in the metabolism of carbohydrates. Within the national research the content of phosphorus in potato tubers was shaped at the level of 1.8-3.9 $\mathrm{g} \cdot \mathrm{kg}^{-1}$ (Zarzecka and Mystkowska, 2004; Wierzbicka, 2012; Zarzecka et al., 2015; Wierzbowska et al., 2016), and in the foreign research it was usually greater and amounted to 2.2-4.9 $\mathrm{g} \cdot \mathrm{kg}^{-1}$ (Elfaki and Abbsher, 2010; Jarvan and Edesi, 2009; Mahamud et al., 2015). Calcium is considered as an element that conditions the correct growth and development of plants. The content of calcium in tubers, within the national research, was within the limits of $0.30-0.69 \mathrm{~g} \cdot \mathrm{kg}^{-1}$ (Kołodziejczyk and Szmigiel, 2005; Wierzbicka and Trawczyński, 2011; Wierzbicka, 2012; Zarzecka et al., 2015), and in the foreign ones 0.2-1.4 $\mathrm{g} \cdot \mathrm{kg}^{-1}$ (Ekin, 2011; Mahamud et al., 2015). Magnesium is a crucial component of potato tubers. Its presence in a plant is determined by the basic processes of metabolism and energy conversion. Magnesium not only participates in approx. 300 enzymatic reactions, but it also constitute an active centre for the chlorophyll molecule. The content of magnesium in dry mass of potato tubers in research carried out by Zarzecka et al. (2006), Wierzbicka and Trawczyński (2011), Wierzbicka (2012) amounted to $0.8-1.3 \mathrm{~g} \cdot \mathrm{kg}^{-1}$, and in foreign researches it reached the level of $3.3 \mathrm{~g} \cdot \mathrm{kg}^{-1}$ (Muhamud et al., 2015). Consumption of $200 \mathrm{~g}$ of potatoes covers between $10-14 \%$ for phosphorus, $8-17 \%$ for magnesium.

Environmental and genetic factors have an impact on the concentration of the mineral components in potato tubers (Horvat et al., 2014; Wierzbowska et al., 2015a, b). The chemical content may change in terms of agrotechnical factors, including biostimulators. Many authors indicated a beneficial impact of biostimulators on the chemical content of potato tubers (Bienia et al., 2018; Trawczyński, 2014; Wierzbowska et al., 2016). Applying biostimulators allows correcting the bad state of nutrition of plants (Fageriai et al., 2009; Fernandez et al., 2013; Singh et al., 2013). The most crucial function performed by biostimulators is the supplementation of a deficiency of components in the period of vegetation, caused by various factors, such as intense plant development, drought, agrotechnical errors. Thus, the objective of research was to specify the impact of the selected biostimulators on the content of phosphorus, calcium and magnesium of three varieties of edible potato.

\section{Materials and methods}

\section{The experimental site}

Potato tubers from the field experiment realized in the years 2015-2017 on an individual farm within the village of Międyrzec Podlaski, Lubelskie voivodeship (51 ${ }^{\circ} 59^{\prime} \mathrm{N}$ and $22^{\circ} 47^{\prime} \mathrm{E}$ ), Poland constituted research material (Fig. 1). The experiment was conducted in three repetitions with the use of split-plot method, on soil regarded as a rye complex, very good, class IVa. In individual years of research, soils differed in the content of organic matter and available macro-elements. In 2015 and 2016, the soil was characterized by slightly acidic reaction, and in the last year of research, alkaline. The content of organic matter ranged from 15.0 to $18.7 \mathrm{~g} \cdot \mathrm{kg}^{-1}$. The content of available phosphorus $(\mathrm{P})$ was from high to very high, potassium $(\mathrm{K})$ from medium to very high, and magnesium $(\mathrm{Mg})$ was high. The first factor was three moderately early varieties of edible potato: Honorata, Jelly and Tajfun, and the second one, four types of biostimulators used in three dates (beginning of flowering, fully flowering and after flowering of plants): 
1. Control variant - without the use of biostimulators spraying with distilled water

2. Biostimulator Kelpak ${ }^{\circledR} \mathrm{SL}$ (active substance - Ecklonia maxima algae extract), containing plant hormones: auxin $-11 \mathrm{mg} \cdot \mathrm{l}^{-1}$ and cytokinin $-0.031 \mathrm{mg} \cdot \mathrm{l}^{-1}$, at a dose of $0.201 \cdot \mathrm{ha}^{-1}$

3. Biostimulator Tytanit ${ }^{\circledR}$ (active substance - titanium) at a dose of $0.201 \cdot$ ha $^{-1}$

4. Biostimulator GreenOk ${ }^{\circledR}$ (active substance - humus substances $20 \mathrm{~g} \cdot 1^{-1}$ ) at a dose of $0.201 \cdot \mathrm{ha}^{-1}$

5. Biostimulator BrunatneBio Złoto (active substances - plant hormones: auxin $0.06 \mathrm{mg} \cdot \mathrm{l}^{-1}$ and cytokinin $\left.-12 \mathrm{mg} \cdot \mathrm{l}^{-1}\right)$ at a dose of $0.20 \mathrm{l} \cdot \mathrm{ha}^{-1}$
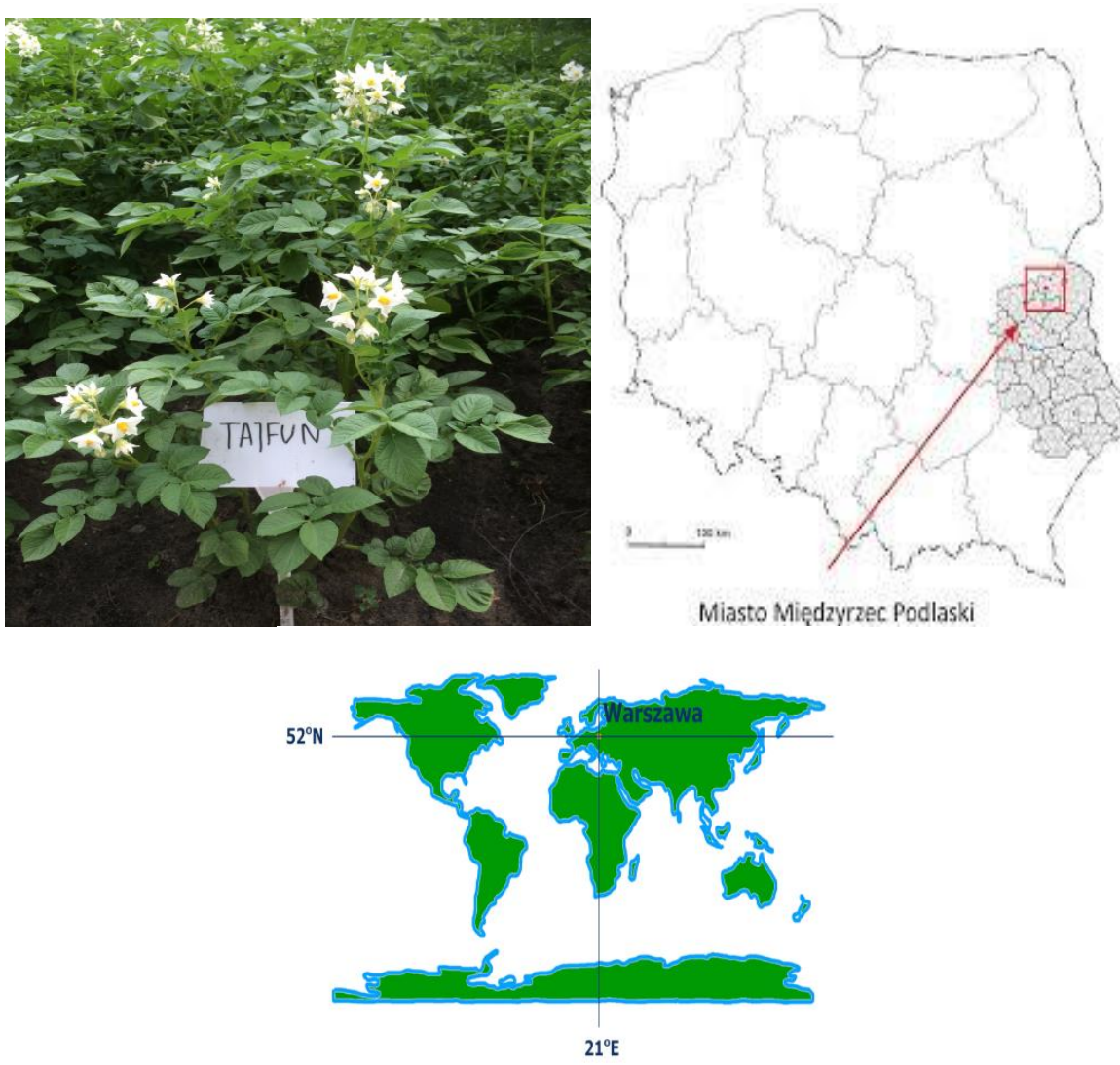

Figure 1. Location of the experiment

The forecrop for potato in particular years of research was winter wheat. After harvesting the forecrop, a team of post-harvest crops was made. In autumn, each year preceding planting, organic fertilization in the form of manure in the amount of $25.0 \mathrm{t} \cdot \mathrm{ha}^{-1}$ and mineral fertilization with phosphorus-potassium in the amount of $\mathrm{P}-$ $44.0\left(100 \mathrm{P}_{2} \mathrm{O}_{5} \cdot 0.44\right) \mathrm{kg} \cdot \mathrm{ha}^{-1}$ (lubofos for potatoes $\left.7 \%\right)$ and $\mathrm{K}-124.5\left(150 \mathrm{~K}_{2} \mathrm{O} \cdot 0.83\right)$ $\mathrm{kg} \cdot \mathrm{ha}^{-1}$ (lubofos for potatoes $25 \%$ ) was applied. These fertilizers were plowed preseason plowing. Nitrogen fertilizers were applied in the spring in an amount of $\mathrm{N}$ $100 \mathrm{~kg} / \mathrm{ha}$ (nitro-chalk 27\%) and mixed with the soil using a cultivator. Potatoes were planted manually under the marker at a spacing of $67.5 \times 37 \mathrm{~cm}$, in the third decade of April $(2015,2016,2017)$. Each plot with an area of $15 \mathrm{~m}^{2}$ accounted for five ridges. Cultivation and care treatments were carried out in accordance with the requirements of 
correct. During the growing season, the potato plantation was protected with the following incidences: Actara $25 \mathrm{WG}$ (thiametoksam) at the rate of $0.08 \mathrm{~kg} \cdot \mathrm{ha}^{-1}$ and Caliypso $480 \mathrm{SC}$ (thiacloprid) at the rate of $0.11 \cdot \mathrm{ha}^{-1}$, and fungicides: Copper Max New $50 \mathrm{WP}$ at the rate of $2.0 \mathrm{~kg} \cdot \mathrm{ha}^{-1}$ and Dithane Neo Tec $75 \mathrm{WG}$ the rate of $2.0 \mathrm{~kg} \cdot \mathrm{ha}^{-1}$. Samples of potato tubers (50 tubers) were taken from each of the plots during harvest in the first decade of September and stored at $10-12{ }^{\circ} \mathrm{C}$, for 8-10 days. Chemical analyses were performed using dry material from 10 representative tubers in three replications.

\section{Chemical analysis methods}

Weight of about 0.2-0.3 g of sample was transferred to vessel and $\mathrm{HNO}_{3}$ and $\mathrm{HCL}$ was added, 3:1 respectively. The vessels were placed in the rotor and loaded to the microwave.

Mineralized samples were transferred to the $50 \mathrm{ml}$ flasks through filtering paper and diluted with ultra-pure water.

Samples were examined with SpectroBlue ICP OES spectrometer at the Regional Research Center for Environment, Agricultural and Innovative Technologies, Pope John II State School of Higher Education in Biała Podlaska. Analytical curves were built by diluting Bernd Kraft Der Standard Spectro Genesis ICAL Solutions and VHG SM68-1500 Element Multi Standard 1 in $5 \% \mathrm{HNO}_{3}$. Operating parameters for ICP OES instrument: coolant flow: $12 \mathrm{l} / \mathrm{min}$; auxiliary flow: $0.90 \mathrm{l} / \mathrm{min}$; nebulizer flow: 0.78 1/min.; pump speed: $30 \mathrm{Rpm}$; number of measurements: 3 .

\section{Meteorological conditions}

Meteorological conditions in the years of potato vegetation have been presented in Table 1 by means of the sum of rainfall and average air temperatures. Vegetation season of 2015 turned out to be the average air temperature of $15.2{ }^{\circ} \mathrm{C}$, higher by $0.2{ }^{\circ} \mathrm{C}$ from the average long-term and rainfall at the level of $295.1 \mathrm{~mm}$. The highest average temperature of air was noted in 2016 and amounted to $15.8^{\circ} \mathrm{C}$, was higher from the average long-term one by $0.8^{\circ} \mathrm{C}$, whilst that year was characterized by the lowest volume of rainfall $-200.9 \mathrm{~mm}$, lower by $134.5 \mathrm{~mm}$ from the long-term sum. The highest number of rainfall was noted in the vegetation season of 2017-325.4 $\mathrm{mm}$ and the lowest air temperature $-14.6{ }^{\circ} \mathrm{C}$ (Table 1).

\section{Results and discussion}

Both genetic and environmental factors have an impact on the concentration of mineral elements in tubers. Many authors indicated that the volume of macro-elements in tubers depended on the particular variety (Wierzbicka and Trawczyński, 2011; Żołnowski, 2013; Muhamud et al., 2015; Wierzbowska et al., 2014, 2016).

The conducted research revealed that the genetic factor had a significant impact on the content of phosphorus in potato tubers (Table 2). The variety which contained the greatest volume of this component was Tajfun variety, followed by Jelly and Honorata varieties. The impact of different properties on the content of phosphorus are underlined by Wierzbowska et al. (2016), Żołnowski (2013). All the applied biostimulators in the presented studies increased the content of phosphorus in the tubers of the tested varieties. The largest average content of phosphorus was obtained after applying BrunatneBio Złoto biostimulator. The experiment conducted by Wierzbowska et al. 
(2016) might be the confirmation of the obtained results, whereby the authors noted an increase of concentration of phosphorus after spraying the plants with Asahi SL, whilst other growth regulators (Bio-Algeen S90, Kelpak SL) did not change the content of phosphorus. Farouk (2015) reported an increase in the content of phosphorus in the tubers after applying biostimulators from the seaweed and potassium humus with respect of the control tubers. Biostimulators (Trifender WP, Asahi SL, Kepak SL, BioAlgeen S90) used in the experiences of Głosek-Sobieraj et al. (2019) did not alter the content of phosphorus. The factor which also significantly modified the content of the analysed element were the hydrothermal conditions appearing in the years of researches. High content of phosphorus was noted in the tubers gathered in 2017, whereby the total rainfall volume was, respectively by 124 and $30 \mathrm{~mm}$ higher than in the years 2016 and 2015 (Table 1).

Table 1. Weather conditions during of potato vegetation

\begin{tabular}{|c|c|c|c|c|c|c|c|}
\hline \multirow{2}{*}{ Years } & \multicolumn{6}{|c|}{ Months } & \multirow{2}{*}{$\begin{array}{c}\text { April- } \\
\text { September }\end{array}$} \\
\hline & April & May & June & July & August & September & \\
\hline \multicolumn{8}{|c|}{ Air temperature $\left({ }^{\circ} \mathrm{C}\right)$} \\
\hline 2015 & 8.2 & 12.3 & 16.5 & 18.7 & 21.0 & 14.5 & 15.2 \\
\hline 2016 & 9.1 & 15.1 & 18.4 & 19.1 & 18.0 & 14.9 & 15.8 \\
\hline 2017 & 6.9 & 13.9 & 17.8 & 16.9 & 18.4 & 13.9 & 14.6 \\
\hline $\begin{array}{c}\text { Multiyear mean } \\
1996-2010\end{array}$ & 8.0 & 13.5 & 17.0 & 19.7 & 18.5 & 13.5 & 15.0 \\
\hline \multicolumn{8}{|c|}{ Rainfall (mm) } \\
\hline 2015 & 30.0 & 100.2 & 43.3 & 62.6 & 11.9 & 47.1 & 295.1 \\
\hline 2016 & 28.7 & 54.8 & 36.9 & 35.2 & 31.7 & 13.6 & 200.9 \\
\hline 2017 & 59.6 & 49.5 & 57.9 & 23.6 & 54.7 & 80.1 & 325.4 \\
\hline $\begin{array}{c}\text { Multiyear sum } \\
(1996-2010)\end{array}$ & 33.6 & 58.3 & 59.6 & 57.5 & 59.9 & 42.3 & 335.4 \\
\hline
\end{tabular}

Table 2. Content of phosphorus in tubers of potatoes depending on the biostimulant used ( $g$ $\mathrm{kg}^{-1}$ dry matter)

\begin{tabular}{c|c|c|c|c|c|c|c}
\hline \multirow{2}{*}{ Variants } & \multicolumn{3}{|c|}{ Cultivars } & \multicolumn{3}{c|}{ Years } & \multirow{2}{*}{ Mean } \\
\cline { 2 - 7 } & Honorata & Jelly & Tajfun & $\mathbf{2 0 1 5}$ & $\mathbf{2 0 1 6}$ & $\mathbf{2 0 1 7}$ & \\
\hline 1. Control variant & 3.112 & 3.261 & 3.321 & 3.221 & 3.261 & 3.417 & $3.265 \mathrm{~d}$ \\
2. Kelpak SL & 3.261 & 3.268 & 3.456 & 3.222 & 3.310 & 3.422 & $3.323 \mathrm{~cd}$ \\
3. Tytanit & 3.187 & 3.364 & 3.461 & 3.268 & 3.367 & 3.458 & $3.350 \mathrm{bc}$ \\
4. GreenOk & 3.281 & 3.411 & 3.467 & 3.393 & 3.450 & 3.466 & $3.411 \mathrm{ab}$ \\
5. BrunatneBio Złoto & 3.371 & 3.485 & 3.512 & 3.473 & 3.471 & 3.567 & $3.479 \mathrm{a}$ \\
\hline Mean & $3.242 \mathrm{c}$ & $3.358 \mathrm{~b}$ & $3.443 \mathrm{a}$ & $3.315 \mathrm{~b}$ & $3.372 \mathrm{~b}$ & $3.466 \mathrm{a}$ & 3.366 \\
\hline
\end{tabular}

The means marked by the same letter do not differ significantly

Phosphorus decides about the processing value of potatoes; its content in tubers amounts to an average of $57 \mathrm{mg} \cdot 100 \mathrm{~g}^{-1}$. Phosphorus is a mineral that occurs in the greatest concentration in human organisms. Upon the recommended standard of $700 \mathrm{mg}$ 
phosphorus per day, $100 \mathrm{~g}$ of potato covers the daily demand of a person for this element in $8 \%$ (Wierzbicka, 2012).

Another important element Solanum tuberosum is calcium, considered as the element which conditions the correct growth and development of an organism and, along with the collagen, it constitute the key building material of the skeletal system (Zarzecka et al., 2015). In an adult human organism, $99 \%$ of calcium occurs in the skeletal system (Friedrich et al., 2002; Miles and Buchman, 2009; Wierzbicka, 2012). The greatest average content of calcium was noted in Tajfun and Honorata varieties, which were in these terms homogeneous, while Jelly variety contained significantly less calcium (Table 3). The applied in the experiment biostimulators increased the content of calcium in the tubers, while the greatest value of calcium was obtained upon the use of BrunatneBio Złoto biostimulator. High content of calcium was indicated in the tubers gathered in 2017 in which the sum of rainfall was higher than in 2016 and 2015 (Table 1). The applied biostimulators reacted to the meteorological conditions in the years of researches causing a significant increase of the content of calcium in 2017, which was characterised by a beneficial distribution of temperatures and rainfall during vegetation period for potatoes (Table 3). All three varieties reacted in a specific manner to the thermal and humidity conditions in place in the years of cultivation, as per the indicated interaction variety x years (Table 4). Wierzbowska e al. (2016) within the presented research, having analysed the impact of Asahi S1, Bio-Algen S90 and Kelpak SL biostimulators, they indicated that the content of calcium in tubers was significantly modified solely by the Asahi Sl biostimulator.

Table 3. Content of calcium in tubers of potatoes depending on the biostimulant used $\left(\mathrm{g} \mathrm{kg}^{-1}\right.$ dry matter)

\begin{tabular}{c|c|c|c|c|c|c|c}
\hline \multirow{2}{*}{ Variants } & \multicolumn{3}{|c|}{ Cultivars } & \multicolumn{3}{c|}{ Years } & \multirow{2}{*}{ Mean } \\
\cline { 2 - 7 } & Honorata & Jelly & Tajfun & $\mathbf{2 0 1 5}$ & $\mathbf{2 0 1 6}$ & $\mathbf{2 0 1 7}$ & \\
\hline 1. Control variant & 0.712 & 0.659 & 0.698 & $0.612 \mathrm{D}$ & $0.687 \mathrm{C}$ & $0.734 \mathrm{BC}$ & $0.684 \mathrm{~d}$ \\
2. Kelpak SL & 0.734 & 0.665 & 0.723 & $0.678 \mathrm{CD}$ & $0.696 \mathrm{C}$ & $0.745 \mathrm{~B}$ & $0.707 \mathrm{~d}$ \\
3. Tytanit & 0.745 & 0.674 & 0.767 & $0.741 \mathrm{~B}$ & $0.734 \mathrm{BC}$ & $0.789 \mathrm{AB}$ & $0.742 \mathrm{bc}$ \\
4. GreenOk & 0.754 & 0.679 & 0.773 & $0.787 \mathrm{~B}$ & $0.779 \mathrm{~B}$ & $0.791 \mathrm{~A}$ & $0.760 \mathrm{ab}$ \\
5. BrunatneBio Złoto & 0.779 & 0.686 & 0.779 & $0.798 \mathrm{~A}$ & $0.834 \mathrm{~A}$ & $0.799 \mathrm{~A}$ & $0.779 \mathrm{a}$ \\
\hline Mean & $0.745 \mathrm{a}$ & $0.673 \mathrm{~b}$ & $0.748 \mathrm{a}$ & $0.723 \mathrm{c}$ & $0.746 \mathrm{~b}$ & $0.772 \mathrm{a}$ & 0.734 \\
\hline
\end{tabular}

The means marked by the same letter do not differ significantly

Table 4. Calcium content depending on the cultivars and years of research $\left(g h a^{-1}\right)$

\begin{tabular}{c|c|c|c}
\hline \multirow{2}{*}{ Cultivars } & \multicolumn{3}{|c}{ Years } \\
\cline { 2 - 4 } & $\mathbf{2 0 1 5}$ & $\mathbf{2 0 1 6}$ & $\mathbf{2 0 1 7}$ \\
\hline Honorata & $0.799 \mathrm{~A}$ & $0.765 \mathrm{~B}$ & $0.769 \mathrm{AB}$ \\
Jelly & $0.676 \mathrm{D}$ & $0.645 \mathrm{D}$ & $0.765 \mathrm{~B}$ \\
Tajfun & $0.773 \mathrm{~A}$ & $0.713 \mathrm{C}$ & $0.754 \mathrm{~B}$ \\
\hline
\end{tabular}

The means marked by the same letter do not differ significantly

A significant component of potato tubers is magnesium the content of which in the tubers depends significantly on the varieties, types of biostimulators and weather conditions in the years of research. Honorata variety gathered the greatest volume of 
magnesium, while Jelly the smallest. Biostimulators caused an increase in the concentration of magnesium with regards to the tubers gathered from the control object. The most mineral components were contained in the tubers after application of BrunatneBio Złoto biostimulator, which allows believing that BrunatneBio Złoto is an agent which acts in a stimulating manner on the gathering of phosphorus, calcium and magnesium. In light of the presented research one must note that the content of magnesium in the tubers depends on the hydrothermal conditions. The largest content of this element was present in the tubers gathered in 2017 (Table 5) which was characterized by excessive rainfall in comparison to the average long-term sum and was the coldest in comparison to the other vegetation periods.

Table 5. Content of magnesium in tubers of potatoes depending on the biostimulant used ( $g$ $\mathrm{kg}^{-1}$ dry matter)

\begin{tabular}{c|c|c|c|c|c|c|c}
\hline \multirow{2}{*}{ Variants } & \multicolumn{3}{|c|}{ Cultivars } & \multicolumn{3}{c|}{ Years } & \multirow{2}{*}{ Mean } \\
\cline { 2 - 7 } & Honorata & Jelly & Tajfun & $\mathbf{2 0 1 5}$ & $\mathbf{2 0 1 6}$ & $\mathbf{2 0 1 7}$ & \\
\hline 1. Control variant & 1.234 & 1.213 & 1.324 & $1.294 \mathrm{D}$ & $1.324 \mathrm{C}$ & $1.412 \mathrm{~B}$ & $1.300 \mathrm{c}$ \\
2. Kelpak SL & 1.325 & 1.245 & 1.345 & $1.312 \mathrm{C}$ & $1.334 \mathrm{C}$ & $1.423 \mathrm{AB}$ & $1.330 \mathrm{bc}$ \\
3. Tytanit & 1.398 & 1.255 & 1.356 & $1.345 \mathrm{C}$ & $1.411 \mathrm{~B}$ & $1.435 \mathrm{~A}$ & $1.367 \mathrm{ab}$ \\
4. GreenOk & 1.457 & 1.278 & 1.366 & $1.356 \mathrm{C}$ & $1.423 \mathrm{AB}$ & $1.456 \mathrm{~A}$ & $1.389 \mathrm{a}$ \\
5. BrunatneBio Złoto & 1.487 & 1.289 & 1.412 & $1.345 \mathrm{C}$ & $1.445 \mathrm{~A}$ & $1.467 \mathrm{~A}$ & $1.407 \mathrm{a}$ \\
\hline Mean & $1.380 \mathrm{a}$ & $1.263 \mathrm{~b}$ & $1.361 \mathrm{a}$ & $1.330 \mathrm{c}$ & $1.387 \mathrm{~b}$ & $1.439 \mathrm{a}$ & 1.360 \\
\hline
\end{tabular}

The mean marked by the same letter do not differ significantly

\section{Conclusions}

The content of phosphorus, calcium and magnesium in potato tubers was substantially diversified by the variety genotype. The largest concentration of phosphorus and calcium was noted in the tubers of Tajfun variety, while magnesium in the tubers of Honorata variety. Tubers of plants treated with BrunatneBio Złoto preparation were characterized by the greatest content of the selected mineral components. Meteorological conditions, especially large volume of rainfall in 2017, contributed to an increase of tested macro-elements (phosphorus, calcium and magnesium) in potato tubers of three edible potato varieties.

Acknowledgements. The results of the research carried out under the research theme NO. 363/S/13 were financed from the science grant granted by the Ministry of Science and Higher Education.

\section{REFERENCES}

[1] Bienia, B., Sawicka, B., Krochmal-Marczak, B. (2018): Influence of foliar fertilization with macro- and microelement fertilizers on the yield and yield structure of several potato varieties. - Fragm. Agron. 35(1): 17-28.

[2] Ekin, Z. (2011): Some analytical quality characteristics for evaluating the utilization and consumption of potato (Solanum tuberosum L.) tubers. - Afr. J. Biotech. 10(32): 60016010 .

[3] Elfaki, A. E., Abbsher, A. M. (2010): Nutritional situation of potato subjected to Sudanese cooking methods. - J. Appl. Sci. Res. 6(8): 880-924. 
[4] Fageria, N. K., Filho, B. M. P., Moreira, A., Guimarăes, C. M. (2009): Foliar fertilization of crop plants. - J. Plant Nutrition 32: 1044-1064.

[5] Farouk, S. (2015): Imroving growth and productivity of potato (Solanum tuberosum L.) by some biostimulants and lithovit with or without boron. - J. Plant Prod., Mansoura Univ. 6(12): 2187-2206.

[6] Fernandez, V., Sotiropoulos, T., Brown, P. (2013): Foliar Fertilization. Scientific Principles and Field Practices. - International Fertilizer Industry Association (IFA), Paris.

[7] Friedrich, M., Jankowiak, D., Ożgo, M., Skrzypczak, W. F., Stepanowska, K. (2002): Mineral Components in Human and Animal Nutrition. - Wyd. Akademii Rolniczej, Szczecin (in Polish).

[8] Głosek-Sobieraj, M., Cwalina-Ambroziak, B., Wierzbowska, J., Waśkiewicz, A. (2018): The influence of biostimulants on the microelement content of tubers in selected potato cultivars. - Acta Sci. Pol. Hortorum Cultus 17(6): 37-48.

[9] Horvat, T., Poljak, M., Lazarević, B., Svećnjak, Z., Hanaćek, K. (2014): Effect of foliar fertilizers on physiological characteristics of potato. - Rom. Agric. Res. 31: 159-165.

[10] Jarvan, M., Edesi, L. (2009): The effect of cultivation methods on the yield and biological quality of potato. - Agron. Res. 7(Special Issue I): 289-299.

[11] Kołodziejczyk, M., Szmigiel, A. (2005): Contents of macronutrients in edible potato tubers depending on the soil complex, variety and fertilization. - Fragm. Agron. 22(1): 436-445.

[12] Leszczyński, W. (2012): Nutritional value of potato and potato products (literature review). - Biul. Ins. Hod. Aklim. Rośl. 266: 5-20 (in Polish).

[13] Mahamud, M. A., Chowdhury, M. A. H., Rahim, M. A., Mohiuddin, K. M. (2015): Mineral nutrient contents of some potato accessions of USA and Bangladesh. - J. Bangladesh Agril. Univ. 13(2): 207-214.

[14] Miles, G. P., Buchman, J. L. (2009): Impact of zebra chip disease on the mineral content of potato tubers. - American Journal of Potato Research 86 481-489.

[15] Singh, J., Singh, M., Jain, A., Bhardwaj, S., Singh, A., Singh, D. K., Bhushan, B., Dubey, S. K. (2013): An Introduction of Plant Nutrients and Foliar Fertilization: A Review. - In: Ram, T. et al. (eds.) Precision Farming: A New Approach. Daya Publishing Company, New Delhi, pp. 252-320.

[16] Tajner-Czopek, A. (2006): Methodology for determining the technological value and quality of potato consumption. - Zesz. Probl. Post. Nauk. Roln. 511: 03-95.

[17] Trawczyński, C. (2014): The influence of amino acid biostimulators - tecamin - on the yield and quality of potatoes. - Ziemn. Pol. 3: 29-34 (in Polish).

[18] Wierzbicka, A. (2012): Mineral content of potato tubers grown in the organic system their nutritional value and interaction. - J. of Research and Applications in Agricultural Engineering 57(4): 188-192 (in Polish).

[19] Wierzbicka, A., Trawczyński, C. (2011): Influence of irrigation and soil microorganisms on the content of macro and micronutrients in organic potato tubers. - Fragm. Agron. 28(4): 139-148.

[20] Wierzbowska, J., Cwalina-Ambroziak, B., Sienkiewicz, S., Głosek, M. (2014): The content of minerals in potato tubers treated with bioregulators. - J. Elementol. 19(2) Suppl. June: 71-72 (in Polish).

[21] Wierzbowska, J., Cwalina-Ambroziak, B., Głosek, M., Sienkiewicz, S. (2015a): Effect of biostimulators on yield and selected chemical properties of potato tubers. - J. Elem. 20(3): 757-768.

[22] Wierzbowska, J., Cwalina-Ambroziak, B., Bowszyc, T., Głosek-Sobieraj, M., Mackiweicz-Walec, E. (2015b): Content of microelements in tubers of potato treated with biostimulators. - Pol. J. Natur. Sc. 30(3): 225-234.

[23] Wierzbowska, J., Cwalina-Ambroziak, B., Głosek-Sobieraj, M., Sienkiewicz, S. (2016): Conttent of minerals in tubers of potato plants treated with bioregulators. - Rom. Agric. Res. 33: 291-298. 
[24] Wójcik-Stopczyńska, B., Grzeszczuk, M., Jakubowska, B. (2012): The content of some nutrients and potentially harmful in edible potatoes from the commercial network. Rocz. Państ. Zak. Hig. 63(3): 207-212 (in Polish).

[25] Zarzecka, K., Mystkowska, I. (2004): Influence of selected herbicides on the content of potassium and phosphorus in potato tubers. -J. Elem. 9(2): 175-182.

[26] Zarzecka, K., Gugała, M., Gąsiorowska, B., Makarewicz, A. (2006): Magnesium and calcium fluctuations in potato tubers influenced by the use of herbicides and their mixtures. - J. Elem. 7: 309-315.

[27] Zarzecka, K., Gugała, M., Mystkowska, I., Baranowska, A., Zarzecka, M. (2015): The comparison of selected mineral content in edible potato tubers. - Zesz. Probl. Post. Nauk Rol. 583: 133-140 (in Polish).

[28] Żołnowski, A. C. (2013): Studies on the Variability of the Yield and Quality of Table Potato (Solanum tuberosum L.) Grown under Varied Levels of Mineral Fertilization. UWM, Olsztyn (Dissertations and Monographs), pp. 191-259 (in Polish). 